\title{
Psychological preparation for dental treatment in children: A randomized clinical
}

\section{study}

\author{
Preparo psicológico para o tratamento odontológico em crianças: Estudo clínico randomizado \\ Preparación psicológica para el tratamiento odontológico en niños: Estudio clínico aleatorizado
}

\author{
Aline Vaneli Pelizzoni \\ ORCID: https://orcid.org/0000-0003-1125-0200 \\ Universidade Estadual do Oeste do Paraná, Brazil \\ E-mail: aline.vaneli@gmail.com \\ Cláudia Silveira Vieira \\ ORCID: https://orcid.org/0000-0002-0900-4660 \\ Universidade Estadual do Oeste do Paraná, Brazil \\ E-mail: clausvieira@gmail.com \\ Rejane Teixeira Coelho \\ ORCID: https://orcid.org/0000-0002-8630-9388 \\ Universidade Estadual do Oeste do Paraná, Brazil \\ E-mail: enajerco@uol.com.br \\ Maria Daniela Basso de Souza \\ ORCID: https://orcid.org/0000-0002-7238-060X \\ Universidade Estadual do Oeste do Paraná, Brazil \\ E-mail: mdanibs@gmail.com \\ Adriano Hoshi \\ ORCID: https://orcid.org/0000-0001-9492-4973 \\ Universidade Estadual do Oeste do Paraná, Brazil \\ E-mail: adrhoshi@gmail.com \\ Isabela Mangue Popiolek \\ ORCID: https://orcid.org/0000-0003-3785-9188 \\ Universidade Estadual do Oeste do Paraná, Brazil \\ E-mail: opiolekiisabela@hotmail.com \\ Natália Gomes do Vale \\ ORCID: https://orcid.org/0000-0003-3665-7496 \\ Universidade Estadual do Oeste do Paraná, Brazil \\ E-mail: natalia_gvw@hotmail.com \\ Ali Hussein Fahs \\ ORCID: https://orcid.org/0000-0003-4220-5349 \\ Universidade Estadual do Oeste do Paraná, Brazil \\ E-mail: alifahs97@hotmail.com \\ Lariana Rafaela Ribeiro Waligura \\ ORCID: https://orcid.org/000-0002-4902-9758 \\ Universidade Estadual do Oeste do Paraná, Brazil \\ E-mail: larianarafaelaw@gmail.com \\ Bárbara Brusco \\ ORCID: https://orcid.org/0000-0001-8030-9144 \\ Universidade Estadual do Oeste do Paraná, Brazil \\ E-mail: babrusco@hotmail.com \\ Lucia Gaiardo \\ ORCID: https://orcid.org/0000-0002-6778-2380 \\ Universidade Estadual do Oeste do Paraná, Brazil \\ E-mail: luciagaiardo@hotmail.com \\ Carlos Augusto Nassar \\ ORCID: https://orcid.org/0000-0002-8647-413X \\ Universidade Estadual do Oeste do Paraná, Brazil \\ E-mail: canassar@yahoo.com \\ Patrícia Oehlmeyer Nassar \\ ORCID: https://orcid.org/0000-0003-3791-0334 \\ Universidade Estadual do Oeste do Paraná, Brazil \\ E-mail: ponassar@yahoo.com.br
}

\begin{abstract}
Objective: to evaluate the psychological preparation in children submitted to dental treatment and to correlate anxiety and fear between children and their parents. Method: randomized clinical study with 26 children divided into two
\end{abstract}


groups, a control group (CG) and an intervention group (IG). The randomized subjects in the IG went through psychological preparation, initially with the presentation of the office, materials and instruments, stimulating their manipulation and clarifying doubts and curiosities about the procedures. Subsequently, the instructional therapeutic toy (ITT) technique was used, first with the story telling "Tigger goes to the dentist" and, later, the subjects dramatized the dentist's role. The CG received the usual treatment at the clinic, based on the talk-show-do technique. Data were collected using two questionnaires, the Children's Fear Survery Schedule Dental Subscale applied to children, and the CORAH scale applied to parents, both pre and post the procedure. Results: the IG initially presented an average in the anxiety and fear score of $29.1 \%$ and after the intervention of $21.5 \%$, demonstrating statistical significance, the CG before the procedure obtained $27.3 \%$ and subsequently $23.2 \%$. The classification of the level of anxiety decreased significantly in both groups, comparing the moments before and after, resulting in $88.5 \%$ with low level of anxiety and $11.5 \%$ with average level. There was no significant correlation between children's anxiety with their parents. Conclusions: it is evident that there are interdisciplinary strategies that reveal more humane paths in the production of health and education and the intervention of psychological preparation and ITT can be applied in other health environments.

Keywords: Child psychology; Anxiety to dental treatment; Comprehensive child health care; Clinical procedures.

\section{Resumo}

Objetivo: avaliar o preparo psicológico em crianças submetidas ao tratamento odontológico e correlacionar a ansiedade e medo entre as crianças e seus pais. Método: Estudo clínico randomizado com 26 crianças divididas em grupo controle (GC) e intervenção (GI). Os sujeitos randomizados no GI passaram por uma preparação psicológica, inicialmente com a apresentação do consultório, materiais e instrumentos, estimulando sua manipulação e esclarecendo dúvidas e curiosidades sobre os procedimentos. Posteriormente, foi utilizada a técnica do brinquedo terapêutico instrucional (BTI), primeiro com a contação de história "Tigrão vai ao dentista" e, posteriormente, os sujeitos dramatizaram o papel do dentista. GC recebeu o tratamento usual na clínica, baseado na técnica de falar-mostrar-fazer. Os dados foram coletados com os questionários Children's Fear Survery Schedule Dental Subscale, aplicados às crianças, e a escala CORAH aplicada aos pais, ambos anterior e posterior ao procedimento. Resultados: O GI apresentou inicialmente uma média no escore de ansiedade e medo de $29,1 \%$ e após a intervenção de $21,5 \%$, demonstrando significância estatística, o GC antes do procedimento obteve $27,3 \%$ e posteriormente $23,2 \%$. A classificação do nível de ansiedade diminuiu significativamente em ambos os grupos, comparando os momentos antes e depois, resultando em 88,5\% com baixo nível de ansiedade e 11,5\% com nível médio. Não houve correlação significativa entre a ansiedade das crianças com seus pais. Conclusões: evidencia-se que há na interdisciplinaridade, estratégias que revelam caminhos mais humanos na produção de saúde e educação e a intervenção do preparo psicológico e o BTI podem ser aplicados em outros ambientes de saúde.

Palavras-chave: Ansiedade ao tratamento odontológico; Odontopediatria; Psicologia da saúde.

\section{Resumen}

Objetivo: evaluar la preparación psicológica en niños sometidos a tratamiento odontológico y correlacionar la ansiedad y el miedo entre los niños y sus padres. Método: Estudio clínico aleatorizado con 26 niños divididos en grupo control (GC) y grupo de intervención (GI). Los sujetos aleatorizados en el GI se sometieron a una preparación psicológica, inicialmente con la presentación de la oficina, materiales e instrumentos, estimulando su manipulación y aclarando dudas y curiosidades sobre los procedimientos. Posteriormente se utilizó la técnica del juguete terapéutico instruccional (ITT), primero con el relato "Tigger va al dentista" y, posteriormente, los sujetos dramatizaron el rol del dentista. GC recibió el tratamiento habitual en la clínica, basado en la técnica talk-show-do. Los datos se recopilaron utilizando los cuestionarios de la subescala dental del programa de supervivencia del miedo em la niñez, aplicados a los niños, y la escala CORAH aplicada a los padres, tanto antes como después del procedimiento. Resultados: El GI presentó inicialmente un promedio en la puntuación de ansiedad y miedo de 29,1\% y luego de la intervención de 21,5\%, demostrando significancia estadística, el GC antes del procedimiento obtuvo $27,3 \%$ y posteriormente $23,2 \%$. La clasificación del nivel de ansiedad disminuyó significativamente en ambos grupos, comparando los momentos antes y después, resultando en un $88,5 \%$ con un nivel bajo de ansiedad y un $11,5 \%$ con un nivel medio. No hubo una correlación significativa entre la ansiedad de los niños con sus padres. Conclusiones: es evidente que existen estrategias interdisciplinarias que revelan caminos más humanos en la producción de salud y educación y la intervención de preparación psicológica y TTI se puede aplicar en otros entornos de salud.

Palabras clave: Ansiedad al tratamiento odontológico; Odontología Pediatrica; Salud psicológica.

\section{Introduction}

Children's experiences are fundamental for the appropriation of concepts and, consequently, prevention and adherence to health treatment. For this reason, (re) thinking the professional practices related to the binomial, health-disease, in an interdisciplinary way produces an expanded praxis in the production of health (Gomes \& Deslades, 1994). 
Anxiety and fear are understood in this study as follows: anxiety is a state of apprehension resulting from internal and or external representatives, real or imagined (Ferreira \& Oliveira, 2016), even when there is no evident danger (Kanegane, Penha, Borsatti \& Rocha, 2003). Fear is characterized as a defensive reaction in threatening and or dangerous circumstances arising from a real object (Perônio, Silva \& Dias, 2003). It is worth mentioning that these psycho-affective reactions are not intrinsic, but learned in contact with social (Bottan, Lehmkuhl \& Araújo).

These infantile reactions can be present in any circumstances of the child's life, but when it comes to health care, these reactions can be more intense depending on the type of procedures to which they will be subjected. Among these health care, there is dental treatment, which has been the object of study, as these psycho-affective reactions influence the postponement of demand for dental professionals and, consequently, in poor oral health conditions. Oral diseases are a public health issue because they have a high prevalence, but they also cause individual and collective impacts regarding pain, discomfort, social and functional limitations that affect the individual's quality of life (Pessoas, Santos, Cruz, Marques \& Lubenow, 2018). As a result of these implications, research has shown interference in oral health care due to anxiety and fear caused by dental treatment (Bottan, Lehmkuhl \& Araújo, 2008; Hass, Oliveira \& Azevedo, 2016; Martins, Belila, Garbin, C. A. S., \& Garbin, 2017; Sanshatone, Bolsson, Pereira, Carpes \& Santos, 2017; Soares, Lima, Barreto \& Colares, 2015).

Correlated to this, studies carried out with children undergoing surgical and invasive procedures have demonstrated the relevance of psychological preparation for reducing anxiety and fear, with positive results in terms of increased treatment adherence and better recovery conditions (Broering, Souza, Kaszubowsi \& Crepaldi, 2018; Broering \& Crepaldi, 2018).

Since not all children have emotional resources that support the possibility of feeling pain and discomfort during dental treatment, as they have not yet subjectively appropriated complex concepts, to which they are exposed when going to the dentist. From this, we ask ourselves, does psychological preparation contributes to the reduction of childhood anxiety and fear for dental treatment?

In the face of this questioning, playful techniques provide an accessible dialogue with the children in order to understand what they are being exposed to. With this, the Instructional Therapeutic Toy (ITT) technique has been shown to be an important ally in care in healthcare settings, as it is an appropriate instrument for the child's cognitive development conditions (Viera, 2020) and contributes to the awareness of aspects about health and its implications for the educational character.

In view of this, the psychological preparation for the emotional confrontation of dental procedures, finds potentiality in the ludic way and, in turn, the reduction of affects that prevent adherence to the treatment and active participation of the patient. For this purpose, this study aims to assess the psychological preparation in children undergoing dental treatment through ITT and to correlate anxiety and fear between children and their parents.

\section{Methodology}

\section{Ethical procedures}

The research was approved by the Ethics Committee in Research with Human Beings upon the substantiated opinion 3,058,363, and registered in the database of the Brazilian Registry of Clinical Trials (ReBEC), registration number RBR-2t5j87. The study relied only on the researchers' own resources.

The data were collected by signing the parents and / or guardians in the Free and Informed Consent Term (ICF), which they authorize their own participation and another term, of equal content, which they consent to the child's participation. In addition, the children expressed their agreement in the Informed Consent Form (FICF). 


\section{Sample}

The sample calculation was performed using the $G *$ Power 3.1.9.2 program, which had an effect size of 0.4 and a test power of 0.95 with a significance level of 0.05 , with a number of participants to compose the sample of 26 children. The sample consisted of children, of both sexes, aged between eight and nine years old, accompanied by their parents and or guardians, which were in a waiting list, at the Odontopediatrics Dental Clinic from June to November 2019.

For the study, the exclusion criteria were observed: not having physical or cognitive disabilities, age less than eight years or more than nine years.

\section{Randomization}

From the screening records, telephone contact was made inviting parents and / or guardians and children to participate to the research. The speech during the call was previously standardized and always performed by the researcher, to follow the same guidelines and clarifications about the research. In the telephone contact, the parents and / or guardians were informed about the objectives and methodology to be used in the research and, later, schedules were offered for scheduling the dental procedure according to the availability of the odontopediatrics clinic. A new telephone contact was made by the researcher, one day before the scheduled date for confirmation of attendance.

The dental procedure chosen to propose the playful intervention was the prophylaxis of oral health. For this, all patients underwent this procedure. Those responsible for the procedure were five academics from the 5th year of the dentistry course, duly calibrated and supervised by their tutors, they performed the service in pairs as recommended by the discipline. The consultations were made individually, with only the child, their guardian, the researcher and the dental staff mentioned above being present in the office.

The groups were formed according to the availability of time for the research participants, times previously available by the institution and randomization. Research participants were matched for age and sex so that there was an equal distribution between groups (Figure 1). 
Figure 1. Diagram of procedures.

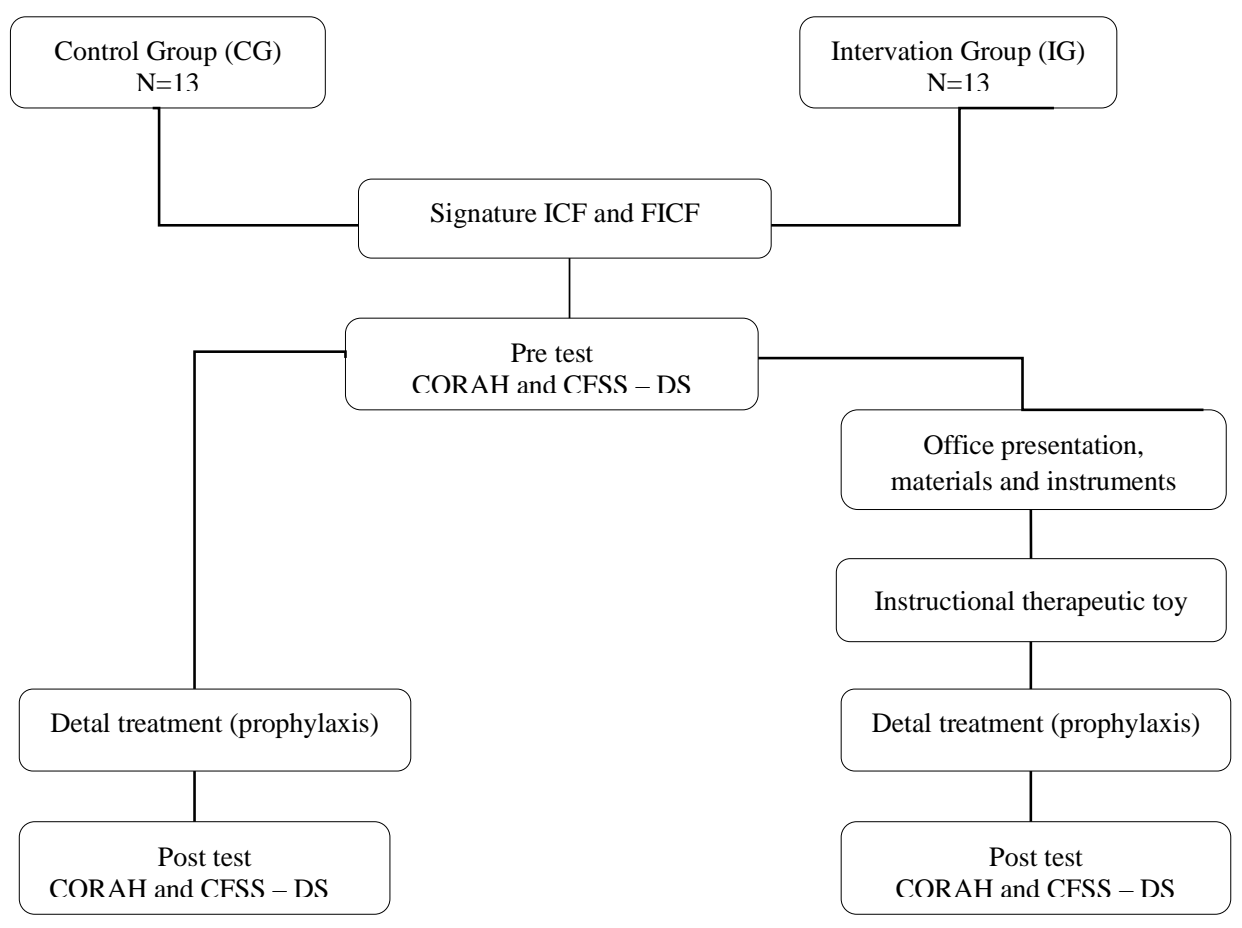

Source: Authors (2020).

\section{Data collection instruments}

The sample was characterized by means of the socioeconomic questionnaire, which included the following axes: Identification data: name, date of birth, age and sex; Developmental information: learning difficulties; cognitive disability or physical disability; Clinical history: prior consultation with the dentist; procedures performed; acceptance of treatment and interruption of treatment; previous psychological treatment and motive; psychotropic use; Responsible data: name; kinship; age; sex; schooling; occupation.

The instruments described below were used in two moments, at the beginning of the consultation, before any procedure and after prophylaxis for both groups. The application was made in the same way, for children and their guardians.

Children's data were collected using the subscale for assessing fear and anxiety about dental treatment in children (CFSS-DS). The scale is divided into four axes related to dental anxiety and fear factors, considering less invasive general aspects, medical aspects, perforation and fear of strangers. The instrument consists in 15 questions related to the feeling of fear when being attended to and exposed to common treatment situations (Barbério, 2017; Cuthbert \& Melamed, 1982).

The alternatives are represented by the Likert scale with five possibilities related to the probability of occurrence of anxiety and fear about each exposed circumstance (Barbério, 2017). These levels are measured on a scale from 1 to 5, without any fear and a lot of fear, respectively. It can vary between 15 to 75 points, considering values lower than 31 points with low anxiety and fear, from 31 to 38 points, considered as medium level and higher than 38 would be with dental anxiety (Cuthbert \& Melamed, 1982).

The guardians' data were collected using the CORAH dental anxiety scale (DAS). It is a psychometric scale composed of four multiple-choice questions related to dental treatment, in which one wonders how one feels close to the time of the consultation with the dentist (Torriani, Teixeira, Pinheiro, Goettems \& Bonow, 2008). There are five alternative answers for each question structured in the Likert Scale. For the sum of the points, the number of the selected alternative is equivalent to the 
value (anxiety level). In this way, responses are quantified in scores from four to twenty, without anxiety until extreme anxiety (Corah, 1968).

The patients were also evaluated during the prophylaxis procedure, regarding signs and symptoms of anxiety and dental fear, and registered in a checklist. The following manifestations of anxiety and fear were considered: verbal exposure; cry; refusal to open your mouth; attempt to avoid treatment; vomiting; aggressiveness. Adaptation by Cardoso \& Loureiro (2005).

\section{Intervention materials and methods}

For the intervention, a kit was created with dental materials and instruments (clinical tweezers, exploratory probe, excavator, toothbrush, Robinson prophylaxis brush and doll with macro arcade (model: plush with macro arcade pet - Tigger). The story "Tigger goes to the dentist" was produced, which was reviewed by a pediatric dentist and a psychologist specializing in child development. The story described all the environmental aspects of the dental office, the disposition of materials and instruments, the type of procedure to which the "Tigger" was submitted, prophylaxis, benefits and guidance on oral health care.

\section{Intervention group}

The intervention was carried out in three consecutive steps, in a single visit, with a pre-established time of 1 hour and 10 minutes. Prior to the intervention, questionnaire data (CFSS-DS and DAS) were collected.

Initially, the clinic space was presented, which contained a dental chair, a sink for hygiene and an auxiliary dental table where the kit materials and instruments were arranged. At that moment, the children were able to handle, raise and lower the dental chair and turn the reflective light on and off. Afterwards, the kit items were explained, about their function and time of use, demonstrating in a tactile way the sensation that the instrument causes in contact with the skin and with the nail. During the exhibition of the environment, participants were encouraged to ask questions and curiosities about the function of objects, instruments and materials;

In the second stage, the story of the "Tigger goes to the Dentist" was told. During the telling of the story, the kid was free to talk and expose their impressions;

In the third stage, the role of the dentist was proposed for the child, offering the therapeutic doll as a "patient". At that moment, the children were able to dress up, with gloves, a cap, apron and use the instruments in the kit. In addition, to be free to talk and ask questions about the procedures they were supposed to be doing.

After these steps, the child was submitted to the prophylaxis and post-test application (CFSS-DS and DAS).

\section{Group control}

The CG was attended using the usual technique of the clinic (talking-showing-doing), in a single appointment, with a pre-established time of 30 minutes. Initially, data collection questionnaires were applied, after prophylaxis and post-test application.

\section{Statistical analysis}

The data were tabulated and stored in two tables in Microsoft ${ }^{\circledR}$ Office Excel version 2013, one containing the children's data and the other the data of the parents and or guardians in the pre and post-test moments.

The data were analyzed using the statistical software SPSS IBM ${ }^{\circledR}$ version 20.0, assuming a 95\% confidence level for all analyzes $(\mathrm{p}<0.05)$.

The Shapiro-Wilk test verified the normality of the data. Initially, descriptive statistics were performed to obtain mean values, standard deviation, 95\% confidence interval, and values of absolute and relative frequency. Student's $t$ test was used to 
verify the difference between the scores of the control group and the intervention group, the $t$ test for paired samples was used to verify the difference between anxiety scores in the pre and post-intervention moments. To analyze the relationship between the children's scores and those responsible, Pearson's correlation test was performed.

\section{Results}

\section{Sample characterization}

The studied population consisted of 26 children aged eight and nine years (61.5\% and 38.5\%, respectively), 16 (61.5\%) children were male and 10 (38.5\%) were women. Parents and guardians had an equal number of participants from 26 people. Regarding kinship, 16 were mothers, five fathers, four grandparents and a stepfather.

The data from the socioeconomic instrument of identification and clinical history are described in Table 1.

Table 1 - Previous experience in dental and psychological treatment.

\begin{tabular}{ccc}
\hline & Accepted treatment & Percent \\
\hline $\begin{array}{c}\text { Previous dental } \\
\text { experience (\%) }\end{array}$ & No problem & 53,8 \\
& Do not accept treatment & 46,2 \\
\cline { 2 - 3 } & Was under psychological treatment & Percent \\
\cline { 2 - 3 } & No (20) & 61,5 \\
Pschological treatment & Yes (6) & 38,5 \\
\hline
\end{tabular}

Source: Author's database (2020).

\section{Children's results in the relationship of anxiety and fear}

The mean score of anxiety and fear was significantly lower in the post-intervention period for both groups. However, there was no significant variation between the mean scores of the control group and the intervention group in both periods, as can be seen in Table 2.

Table 2 - Anxiety and fear scores in the control and intervention groups before and after intervention.

\begin{tabular}{cccccc}
\hline Group & Anxiety score & Average & SD & CI95\% & P value \\
\hline \multirow{2}{*}{ General } & Pre & 28,2 & 7,2 & $25,2-31,1$ & \multirow{2}{*}{ Post } \\
\cline { 2 - 6 } Control & Pre & 22,3 & 5,9 & $19,9-24,7$ & $<0,001^{*}$ \\
& Post & 27,31 & 6,4 & $23,3-31,2$ & \multirow{2}{*}{$0,001^{*}$} \\
\cline { 2 - 6 } Intervention & Pre & 29,23 & 6,4 & $19,3-27,1$ & \\
& Post & 21,5 & 5,1 & $24,2-31,1$ & \multirow{2}{*}{$0,001^{*}$} \\
& & & & $18,1-24,9$ & \\
\hline
\end{tabular}

SD: Standard deviation; CI95\%: confidence interval 95\%; *: there is a significant difference between the pre- and post-intervention period. Source: Authors. 
Table 3 shows the classification of the level of anxiety and fear in the control and intervention groups before and after the evaluation, in which there is a decrease in the classification of levels of dental anxiety and fear in the moments before and after for both groups.

Table 3 - Classification of the level of anxiety and fear in the control and intervention groups before and after intervention.

\begin{tabular}{|c|c|c|c|c|}
\hline Stage & Group (n) & Low n (\%) & Average n (\%) & High n (\%) \\
\hline & General (26) & $17(65,4)$ & $5(19,2)$ & $4(15,4)$ \\
\hline \multirow[t]{3}{*}{ Pre } & Control (13) & $8(61,5)$ & $4(30,8)$ & $1(7,7)$ \\
\hline & Intervention (13) & $9(69,2)$ & $1(7,7)$ & $3(23,1)$ \\
\hline & General (26) & $23(88,5)$ & $3(11,5)$ & 0 \\
\hline \multirow[t]{2}{*}{ Post } & Control (13) & $11(84,6)$ & $2(15,4)$ & 0 \\
\hline & Intervention (13) & $12(92,3)$ & $1(7,7)$ & 0 \\
\hline
\end{tabular}

$\%$ relative to the group. Source: Authors.

The CG, in the pre-test, presented $61.5 \%$, corresponding to 8 children in the total group classified as low level of anxiety and fear, with an average score of $30.8 \%$, representing 4 children, and high level $7.7 \%$, which corresponds to a child. After the service, the group had an increase in the number of children with a low level of anxiety and fear $84.6 \%$, making a total of 11 children, and $15.4 \%$, indicated two children with medium grade. At the time of the test, the sample did not show a high score for anxiety and fear.

In the IG, the pre-test found $69.2 \%$, representing 9 children in the total group with a low score, $7.7 \%$, a child with a medium grade and $23.1 \%$, three children with a high level of anxiety and fear. After the intervention, $92.3 \%$ of the total group was identified, corresponding to 12 children with a low score, and only $7.7 \%$, only a child with a medium degree without evidence of a high state of dental anxiety and fear.

The general indicators showed that the total sample, composed of 26 children, after intervention $88.5 \%$, represents 23 children who showed low anxiety and fear scores, and $11.5 \%$, three medium level children.

Table 4 shows the individual difference in the questions in the CFSS-DS questionnaire. 
Table 4 - Difference between pre and post responses to the CFSS-DS questionnaire.

\begin{tabular}{|c|c|c|c|c|}
\hline Question & Group & Average & SD & P-value \\
\hline \multicolumn{5}{|l|}{ How afraid are you of: } \\
\hline \multirow{2}{*}{ 1. Dentists } & Pre & 1,42 & 0,7 & \multirow{2}{*}{$0,050^{*}$} \\
\hline & Post & 1,15 & 0,4 & \\
\hline \multirow{2}{*}{ 2. Doctors } & Pre & 1,69 & 1,1 & \multirow{2}{*}{0,739} \\
\hline & Post & 1,77 & 1,2 & \\
\hline \multirow{2}{*}{ 3. Injections } & Pre & 3,54 & 1,4 & \multirow{2}{*}{$0,005^{*}$} \\
\hline & Post & 2,77 & 1,5 & \\
\hline \multirow{2}{*}{ 4. Having someone examine your mouth } & Pre & 1,23 & 0,8 & \multirow{2}{*}{0,678} \\
\hline & Post & 1,15 & 0,4 & \\
\hline \multirow{2}{*}{ 5. Having to open your mouth } & Pre & 1 & 0 & \multirow{2}{*}{0,327} \\
\hline & Post & 1,04 & 0,1 & \\
\hline \multirow{2}{*}{ 6. Having a stranger touch you } & Pre & 2,58 & 1,4 & \multirow{2}{*}{$0,018 *$} \\
\hline & Post & 1,96 & 1,2 & \\
\hline \multirow{2}{*}{ 7. Having somebody look at you } & Pre & 2 & 1,1 & \multirow{2}{*}{0,067} \\
\hline & Post & 1,62 & 1,1 & \\
\hline \multirow{2}{*}{ 8. The dentist drilling } & Pre & 1,77 & 1,1 & \multirow{2}{*}{$0,007 *$} \\
\hline & Post & 1,15 & 0,6 & \\
\hline \multirow{2}{*}{ 9. The sight of the dentist drilling } & Pre & 1,35 & 0,9 & \multirow{2}{*}{0,265} \\
\hline & Post & 1,12 & 0,3 & \\
\hline \multirow{2}{*}{ 10. The noise of the dentist drilling } & Pre & 1,46 & 0,7 & \multirow{2}{*}{0,11} \\
\hline & Post & 1,19 & 0,4 & \\
\hline \multirow{2}{*}{$\begin{array}{l}\text { 11. Having somebody put instruments in } \\
\text { your mouth }\end{array}$} & Pre & 2,08 & 1,3 & \multirow{2}{*}{$0,005^{*}$} \\
\hline & Post & 1,23 & 0,4 & \\
\hline \multirow{2}{*}{ 12. Choking } & Pre & 3,19 & 1,5 & \multirow{2}{*}{$0,001 *$} \\
\hline & Post & 2,12 & 1,2 & \\
\hline \multirow{2}{*}{ 13. Have to go to the hospital } & Pre & 2,42 & 1,4 & \multirow{2}{*}{$0,013 *$} \\
\hline & Post & 1,88 & 1,2 & \\
\hline \multirow{2}{*}{ 14. People in White uniforms } & Pre & 1,42 & 1,1 & \multirow{2}{*}{0,129} \\
\hline & Post & 1,14 & 0,7 & \\
\hline \multirow{2}{*}{ 15. Having the nurse clean your teeth } & Pre & 1,08 & 0,2 & \multirow{2}{*}{1} \\
\hline & Post & 1,08 & 0,2 & \\
\hline
\end{tabular}

SD: Standard deviation. *: There is a significant difference. Source: Authors.

As for the data collected in the checklist, it was found that, in the entire sample, the children were collaborative, without showing signs of anxiety and fear, such as those described in the literature.

\section{Results of the relationship between anxiety and fear between children and their guardians}

Anxiety levels showed a strong and significant relationship in the pre- and post-intervention moments when using the patient as their own control $(\mathrm{r}=0.727 *)$, the same occurred for the values of those responsible $(\mathrm{r}=0.967 *)$. The children's anxiety scores were not significantly related to the parents' anxiety scores. 
Table 5 - Correlation values between children's anxiety scores with those responsible

\begin{tabular}{ccccc}
\hline & $\begin{array}{c}\text { Children pre } \\
\text { Anxiety }\end{array}$ & $\begin{array}{c}\text { Children post } \\
\text { Anxiety }\end{array}$ & $\begin{array}{c}\text { Responsable pre } \\
\text { anxiety }\end{array}$ & $\begin{array}{c}\text { Responsable post } \\
\text { anxiety }\end{array}$ \\
\hline Children pre anxiety & 1 &, $727^{*}$ & $-0,025$ & $-0,102$ \\
Children post anxiety & 1 & $-0,136$ & $-0,106$ \\
$\begin{array}{c}\text { Responsable pre } \\
\text { anxiety }\end{array}$ & & 1 &, $967^{*}$ \\
$\begin{array}{c}\text { Responsable post } \\
\text { anxiety }\end{array}$ & & & \\
\hline
\end{tabular}

*: significant correlation. Source: Authors.

\section{Discussion}

The psychological intervention, to prepare children for dental treatment with ITT, showed a decrease in anxiety and fear in the post-intervention period, in relation to the pre-intervention, for both groups. What contributed to the patient's wellbeing, in the relationship with the dental professional and with the treatment itself. Accordingly, a recent study proved the effectiveness of psychotherapeutic, cognitive-behavioral care in Norwegian children and adolescents, between 10 and 16 years old, using the CFSS-DS scale (Berge, Agdal, Vika \& Skeie, 2017).

The same was evidenced in the classification between the levels of anxiety and fear (table 3), in low, medium and high. In the post-test moment, both groups represented the majority with a low level of anxiety and fear, which demonstrates effectiveness in the service in both techniques. However, there was no statistical significance between the techniques: psychological intervention with ITT, performed in the IG, and the usual clinic technique, talk-show-do, undertaken in the CG.

In addition, the literature is concise in relation to pediatric pediatric practice associated with ludic activities, especially with an educational nature, as the appropriation of knowledge in childhood will help later health care. It is noticed that when approaching the technical aspects through play, the child becomes instrumentalized and becomes active in his treatment (Sigaud, Santos, Costa \& Tiriyama, 2016).

The possibility of retelling the story at ITT, creates an environment that allows action and mastery over dental instruments and materials and gives the child greater involvement with the experience. Likewise, the role of the dentist brings the child closer to reality. In other words, play transforms the implicit content into meaning that connects the child to the objective reality of oral care, producing what is most noble in the child-adult relationship, teaching-learning (Martins, 2013; Pino, 2004).

It is evident that some dental procedures will not stop causing discomfort or pain, but when the child relates to reality, he develops the cognitive-affective unit, and acquires conditions to deal with unpleasant situations in a conscious, active and coresponsible way (Pasqualini, 2013; Martins, 2013; Vigotski, 2001).

The individual analysis of the CFSS-DS questions, showed a significant difference in the mean scores in the questions that measured the fear of going to the dentist (1), of anesthesia (3), a person who does not know himself, touching you (6), the dentist's motor (8), a person putting instruments in his mouth (11), choking (12), and going to the hospital (13). It is interesting to note that the intervention proposal did not include invasive procedures such as anesthesia. However, the responses confirmed effectiveness in reducing anxiety and fear even in an invasive procedure.

The questions about how much fear they felt about going to the doctor (2), someone examining your mouth (4), having to open your mouth (5), someone looking at you (7), seeing the dentist's motor (9), noise from the dentist's engine (10), a person 
with white clothing (14), and having someone cleaning their teeth (15), did not show any significant difference in the pre and post test averages. There is no study in the literature that describes the reasons for some fears to stand out from others, as questioned in the CFSS-DS, or which intervention has the greatest benefits on each of the issues.

Prophylaxis visits were recorded without manifestations of anxiety or fear as described in the literature. It is worth considering that prophylaxis is a painless procedure, in general, it does not cause discomfort, pain or generates anxiety, except in children under six years of age (Ferreira \& Oliveira, 2016). A study carried out in 2015, proved the significant correlation between anxiety and invasive procedures (cavity preparation, anesthesia, and extraction) superior to non-invasive treatments (clinical examination and prophylaxis) (Melo, Lima, Moura, Silva, Gondim \& Moreira, 2015).

Here, the importance of the pediatric pediatric technique with the instrument (speak-show-do), practiced at the study site in association with ITT, is supported as an increase in knowledge about the treatment, maintenance and recovery of health(Pontes, Tabet, Folkmann, Cunha \& Almeida, 2016).

The initial assumption that related childhood anxiety and fear to parents, referred to in the literature, did not show statistical significance in the population studied. Research carried out in 2016, presented results similar to those evidenced in the research, in which there is no statistically significant relationship between dental anxiety of parents and children (table 5) (Ferreira \& Oliveira, 2016). However, research points to a negative influence on treatment when there is participation of those responsible and a significant correlation between dyad anxiety (Tovo, Faccin \& Vivian, 2016; Moreira, Imparato, Teixeira, Reis, Navarro \& Drugowick, 2015).

The correlation in the children's scores, when taken as their own control, was statistically significant and strong and the same occurred with the correlation of the parents' pre and post-tests (Table 5). This, affirms the correlation between the evaluated moments.

The importance of considering all the moments of the intervention is recorded, starting with the reception of the child and his / her guardian, in which the professional presents himself / herself and is available to listen to the patient's needs. In this sense, patients were instructed to clear up their doubts and expose their ideas about treatment, giving patients confidence and openness to express their feelings, which helps to reduce anxiety and fear (Silva, Freire, Santana \& Miasato, 2016). The patients were also encouraged by the students during the consultation, demonstrating safety and tranquility in carrying out the prophylaxis.

In this regard, it is considered that the relationship established between the professional and the patient is a strong ally to transmit safety and, therefore, reduce anxiety and fear, considering that the relationship between the child, parents and professional in view of the success of the treatment (Tomé, et al., 2019).

It is also worth highlighting the influences of the environment on the oral health situation, which will support the dentist in the treatment guidelines, understanding health-disease as a historical process, influenced by cultural paradigms that associate treatment with pain and social limits such as difficulties in accessing public or private services due to the financial cost (Costa, 2002).

Therefore, it is clear the relevance of the health professional's praxis to elucidate the concepts of health and provide conditions for the subject to act on the health-disease process itself, making him autonomous and responsible for his body.

The interface between knowledge in the areas of health, provides conditions for the creative and transforming production of reality with oral health care. So, the areas can incorporate different methods of knowledge production for the production of oral health. It is conjectured that these are complementary and can appropriate each other's knowledge to use them in the routine of the dental clinic.

It is noteworthy that no records were found in the literature comparing techniques in pediatric dentistry, which individually measure the anxiety levels of the questions in the CFSS-DS questionnaire. Research on this has shown statistical 
significance in reducing anxiety and fear of some situations questioned in relation to others. The individual in-depth examination of the questions that make up the test is considered relevant and the relationship with the interventional techniques of psychological preparation.

It should be noted that the techniques presented in this study are also relevant to the performance in primary care, as they constitute elements that produce oral health and can be disseminated to other specialties. In this sense, ITT is an instrument that can be used in various health environments, as an important method for producing learning and developing awareness. What makes it possible to take care of aspects of your physical and psychological health, resizing fear and anxiety.

\section{Final Considerations}

It is evident that there are interdisciplinary strategies that reveal more humane paths for the production of health and education.

Although the psychological phenomenon is an object of study in psychology, it is noted that psychological preparation can be inserted in the practices of other areas of health. However, it is necessary for professionals to be instrumentalized and base their performance following the theoretical and scientific rigor.

It is noteworthy that there was no statistically significant difference between psychological preparation and the clinic's usual technique (speaking-showing-doing), and that both aim at the subject's knowledge about a given situation. However, ITT, as a procedure applied to psychological preparation, results in a deepening of the affective-cognitive unit that imply the child's vicissitudes regarding their care. Ultimately, the integration between education and health is a fundamental element to promote the development of responsible individuals committed to their own care.

Finally, it is confirmed that this is an excerpt from a larger work, which proposed a quanti-quali intervention, crossed by the perspective of historical-cultural psychology.

\section{References}

Barbério, G. S. (2017). Confiabilidade e validade do questionário Children's Fear Survey Schedule-Dental Subscale para avaliação do medo e ansiedade ao tratamento odontológico em crianças. Doutorado em Ciências Odontológicas Aplicadas, Universidade de São Paulo. Bauru, Brasil.

Berge, K. G., Agdal, M. L., Vika, M. \& Skeie, M. S. (2017). Tretment of intra-oral injection phobia: a randomized delayed intervention controlled trial among Norwegian 10-to 16-year-olds. Acta odontológica Scandinavica, 7, 294-301

Bottan, A. M. B., Lehmkuhl, G. L. \& Araújo, S. M. (2008). Ansiedade no tratamento odontológico: estudo exploratório com crianças e adolescentes de município de Santa Catarina. RSBO, 5 (1), 13-19.

Broering, C. V. \& Crepaldi, M. A. (2018). Percepções e informações das mães sobre a cirurgia de seus filhos. Fractal, Rev. Psicol, $30(1), 3-11$.

Broering, C. V., Souza, C. D., Kaszubowsi, E. \& Crepaldi, M. A. (2018). Efeitos de preparações psicológicas pré-cirúrgicas sobre o estresse e a ansiedade de meninos e meninas. Acta colomb. Psicol, 21 (1), 217-227.

Cardoso, C. L. \& Loureiro, S. R. (2005). Problemas comportamentais em crianças com ansiedade frente ao tratamento odontológico. Estudos de Psicologia, 22: $5-12$.

Corah, N. L. (1968). Development of a dental anxiety scale. Department of Behavioral Science, School of Dentistry, State University of New York at Buffalo, Buffalo.

Costa Junior, A. L.(2002). Psicologia aplicada à odontopediatria: uma introdução. Estudos e pesquisas em Psicologia, 2 (2)

Cuthbert, M. I. \& Melamed, B. G. (1982). A screening device: children at risk for dental fears and management problems. Journal of dentistry for children.

Ferreira, H. A. C. M. \& Oliveira, A. M. G. (2016). Ansiedade entre crianças e seus responsáveis perante o atendimento odontológico. Rev. Odontol. Univ. Cid. $29(1), 6-17$.

Gomes, R. \& Deslandes, S. F. (1994). Interdisciplinaridade na saúde pública: um campo em construção. Rev Lat Am Enfermagem, 2 (2), $103-114$.

Hass, M. G. M., Oliveira, L. J. C. \& Azevedo, M. S. (2016). Influência da vestimenta do cirurgião-dentista e do ambiente do consultório odontológico na ansiedade de crianças pré-escolares durante consulta odontológica: resultados de um estudo piloto. RFO UPF, 21 (2), $201-207$. 
Kanegane, K., Penha, S. S., Borsatti, M. A. \& Rocha, R. G. (2003). Dental anxiety in na emergency dental servisse. Rev saúde pública, 37 (6), $786-792$

Martins, L. M. (2013). O desenvolvimento do psiquismo e a educação escolar: contribuições à luz da psicologia histórico-cultural e da pedagogia históricocrítica. Campinas: Autores Associados

Martins, R. J., Belila, N. M., Garbin, C. A. S. \& Garbin, A. J. I. (2017). Medo e ansiedade dos estudantes de diferentes classes sociais ao tratamento odontológico. Arch Health Invest, 6 (1), 43-47.

Melo, R. B., Lima, F.C., Moura, G. M., Silva, P. B. G., Gondim, J. O. \& Moreira-Neto, J. J. S. (2015). Avaliação da relação entre procedimentos odontológicos e comportamento infantil. Rev. Odontol. Bras. Centra, 24 (68), 20-25.

Moreira, K. M. S., Imparato, J. C. P., Teixeira, K. B., Reis, J. B., Navarro, R. S. \& Drugowick, R. M. (2015). Ansiedade do responsável em relação ao atendimento odontopediátrico. Rev. Assoc Paul Cir Dent, 69 (2), 135-141

Pasqualini, J. C. (2013). Periodização do desenvolvimento psíquico à luz da escola de Vigotski: a teoria histórico-cultural do desenvolvimento infantil e suas implicações pedagógicas. In: Marsiglia ACG, ed. Infância e pedagogia histórico-crítica. (4a ed.), 71-97, Autores associados

Perônio, T. N., Silva, A. H. \& Dias, S. M. (2019). O medo frente ao tratamento odontológico no contexto do Sistema Único de Saúde: uma revisão de literatura integrativa. $B B O, 29(1), 37-43$.

Pessoas, A. V. C., Santos, A. F., Cruz, D. S. M., Marques, D. K. A. \& Lubenow, J. A. M. (2018). Brinquedo terapêutico: preparo de crianças em idade préescolar para punção venosa. Rev ciências da saúde Nova Esperança. 16 (1), 64-72.

Pino, A. (2004). Ensinar-aprender em situação escolar: perspectiva histórico-cultural. Contrapontos, 4 (3), $439-460$.

Pontes, J. E. D, Tabet, E., Folkmann, M. A. S., Cunha, M. L. R. \& Almeida, F. A. (2016). Therapeutic play: preparing the child for the vaccine. Einstein, 13 (2), $238-242$

Sanshotene, M.C., Reis, A. C. M., Bolsson, G. B., Pereira, K. C. R., Carpes, A. D. \& Santos, B. Z. (2017). Ansiedade, estresse e fatores associados na clínica odontológica infantil. Disciplinarum Scientia, 18 (1), 39-57.

Sigaud, C. H. S., Santos, B. R., Costa, P., Tiriyama, A. T. M. (2016). Promoção da higiene bucal de pré-escolares: efeitos de uma intervenção educativa lúdica. Rev. Bras Enferm, 70 (3), 545-51

Silva, L. F. P., Freire, N. C., Santana, R. S. \& Miasato, J. M. (2016). Técnicas de manejo comportamental não farmacológicas na odontopediatria. Rev. Odontol, $28(2), 135-142$

Soares, F. C., Lima, D. S. M., Barreto, K. A. \& Colares, V. (2015). A ansiedade odontológica em crianças e os fatores associados: revisão de literatura. Psicologia, Saúde \& Doenças, 16 (3), 373-385.

Tomé, M. S. S., Neto, R. S. M., Alencar, A. A., Alves, I. F. S., Lopes, K.S. \& Carneiro, S. V. (2019). Avaliação da ansiedade dos pais e/ou responsáveis frente ao tratamento odontológico em crianças. Braz. J. Srug. Clin. Res, 25 (1), 13-16

Torriani, D. D., Teixeira, A. M., Pinheiro R., Goettems, M. L. \& Bonow, M. L. M. (2008). Adaptação transcultural de instrumentos para mensurar ansiedade e comportamento em clínica odontológica infantil. Arq.Odontol, 44 (4), 17-23.

Tovo, M. F., Faccin, E. S. \& Vivian, A. G. (2016). Psicologia e odontopediatria: contextualização da interdisciplinaridade no Brasil. Alethéia, 49 (2), 76-88

Viera, C. S. (2020) Técnicas de enfermagem em pediatria. In: Collet, N., Oliveira, B. R. G. \& Viera, C. S. Manual de enfermagem em pediatria. (2a ed.), 139279, Goiânia: AB

Vigotskii, L. S. (2001). Aprendizagem e desenvolvimento intelectual na idade escolar. In: Vigotskii, L. S., Luria, A. R. \& Leontiev, A. N. Linguagem, desenvolvimento e aprendizagem. (7a ed.), 103-117, Ícone 